\title{
Veress needle versus direct trocar entry for laparoscopy: a retrospective study
}

\author{
Sushma Sinha ${ }^{1}$, Surya Malik ${ }^{2 *}$ \\ ${ }^{1}$ Department of Obstetrics and Gynecology, ABGH Hospital, Government of NCT of Delhi, India \\ ${ }^{2}$ Department of Obstetrics and Gynecology, King Khalid Hospital, Alkharj, Riyadh, Saudi Arabia
}

Received: 10 October 2018

Accepted: 01 November 2018

*Correspondence:

Dr. Surya Malik,

E-mail: surya85.sm@gmail.com

Copyright: () the author(s), publisher and licensee Medip Academy. This is an open-access article distributed under the terms of the Creative Commons Attribution Non-Commercial License, which permits unrestricted non-commercial use, distribution, and reproduction in any medium, provided the original work is properly cited.

\begin{abstract}
Background: The aim of this paper is to compare the outcomes of veress needle entry versus direct trocar for laparoscopy in terms of the duration of the procedure, ease of performance and the complications encountered during each technique.

Methods: The present study was conducted on a retrospective basis from April '2008 to September 2017, in the dept of Obstetrics and Gynecology, in a 100 bedded hospital, ABGH hospital. All the cases who underwent laparoscopic ligation procedure during this time were taken into account. From 2008 to 2012 traditional technique of veress needle entry was used for access(group -1) but it had been switched over to direct trocar since 2013(group -2) These two groups were compared in terms of the demographic profile, duration of procedure, previous h/o surgical interventions ,ease of performance and various complications encountered during the procedure.

Results: The total number of patients who underwent ligation during this period were 1912, which were divided into two groups ,till 2012(veress needle entry group,group-1) 754 patients(39.44\%), and after 2012 (direct trocar,group -2) 1158 patients $(60.56 \%)$.Duration of procedure was $4.5 \pm 1.2 \mathrm{~min}$ in group 1 which was significantly higher than group $2,2.2 \pm 0.8 \mathrm{~min}(\mathrm{p}$-value $<0.001)$. Amount of gas required was greater in group $1,4.9 \pm 1.3$ lts as compared to group $2,2.4 \pm 0.51$ ts.

Conclusions: Direct trocar entry is a reliable alternative to traditional technique for pneumoperitoneum establishment and should be regarded as a part of the surgical armamentarium of a trained laparoscopic surgeon.
\end{abstract}

Keywords: Pneumoperitoneum, Surgical Interventions, Veress needle

\section{INTRODUCTION}

Over the last decade, a rapid increase has occurred in both the applications of operative laparoscopy and the number of surgeons using this technique. Although the complications of operative laparoscopy are low, they can be severe and lifethreatening. ${ }^{1}$

A search of the Manufacturer and User Facility Device Experience Database (MAUDE) from the Medical Device section of the Food and Drug Administration's
Website lists 25 serious iatrogenic injuries involving Veress needle entry between between March 1992 and May $2000 .^{2}$

A search of "trocar" and "pneumoperitoneum" yielded 17 serious iatrogenic injuries reported between January 1993 and May 2000. A previous review of the same website by Bhoyrul et al 3 analysed the data on all reported trocar injuries through 1996. They identified 629 trocar injuries. Injuries included 408 to major vascular structures, 182 to other viscera (mostly bowel), and 30 abdominal wall 
hematomas. Twenty-seven vascular injuries (7\%) occurred during trocar insertion or reinsertion without pneumoperitoneum or with the use of excessive force.

Access into the abdomen is the one challenge of laparoscopy that is particular to the insertion of surgical instruments through small insertions. Laparoscopy is currently widely used in the practice of medicine, for both diagnostic and therapeutic purposes.

Complications arising from laparoscopic surgery are rare and commonly occur when attempting to gain access to the peritoneal cavity.

Creation of the pneumoperitoneum is the first and most critical step of a laparoscopic procedure because that access is associated with injuries to the gastrointestinal tract and major blood vessels and at least $50 \%$ of these major complications occurs prior to commencement of the intended surgery. ${ }^{4}$ Table 1 depicts the incidence of major complications associated with the various techniques of abdominal entry as reported in a review of selected studies. ${ }^{5-9}$

Table 1: Complication rates based on technique of abdominal entry.

\begin{tabular}{|l|l|}
\hline Technique & Complication rate per 1000 \\
\hline Direct trocar & $0.6-1.1$ \\
\hline Veress needle & $0.3-2.7$ \\
\hline Open laparoscopy & $0.6-12.0$ \\
\hline First trocar & $1.9-2.7$ \\
\hline Accessory trocar & $0.8-6.0$ \\
\hline
\end{tabular}

\section{METHODS}

The present study was conducted on a retrospective basis from April '2008 to September' 2017 in the department of Obstetrics and Gynaecology of a 100 bedded hospital ABGH hospital, Government of NCT of Delhi.

All the cases who underwent laparoscopic tubal ligation procedure during this time were taken into account. From 2008 to 2012 traditional technique of Veress Needle entry was used for access (Group 1), but it has had been switched over to direct trocar entry since 2013 (Group 2).

The total number of patients who underwent ligation during this period were 1912, which were divided into two groups, till 2012 (veress needle entry group, group1), 754 patients $(39.44 \%$ ); and after 2012 (direct trocar group-2), 1158 patients $(60.56 \%)$.

Direct Trocar Entry Technique: After the institution of general anaesthesia, the patient is placed in the dorsal supine position with her legs in Allen stirrups. She is then prepped and draped in the usual sterile fashion.

The procedure involved local skin and subcutaneous tissue infiltration with $1 \%$ xylocaine local anaesthetic, infraumbilical skin incision wide enough (approx $1 \mathrm{~cm}$ ) to accommodate the diameter of sharp trocar $(10 \mathrm{~mm})$. The anterior abdominal wall is then elevated and then the trocar is inserted at a 90-degree angle.

The trocar is advanced in a controlled fashion into the peritoneal cavity with a twisting semicircular motion. The laparoscope is then introduced, proper intraperitoneal placement ascertained, and pneumoperitoneum created .

The pre-op evaluation included age of patients, body mass index (BMI), prior surgical interventions. The intraoperative data collection included time of umbilical incision to time of telescope removal (in min), amount of gas required during the procedure (in litres) and all the major and minor complications encountered during the procedure.

The post-operative data included any late complications like wound infection. Statistical analysis was done for all the variables that were studied. Comparison was done in both groups and then the p-value was calculated. P-value $<0.05$ was considered significant.

\section{RESULTS}

In this retrospective study of 1912 patients, demographic profile was almost similar in both the groups. Mean age in group 1 and group 2 was $30.51 \pm 4.32$ years and $30.94 \pm 4.18$ years respectively (Table 2 ).

Table 2: Age distribution of patients.

\begin{tabular}{|l|l|l|}
\hline Age(years) & Group 1(n-754) & Group 2(n-1158) \\
\hline $21-25$ & $68(9 \%)$ & $84(7.25 \%)$ \\
\hline $26-30$ & $284(37.7 \%)$ & $464(40.07 \%)$ \\
\hline $31-35$ & $342(45.75 \%)$ & $474(40.93 \%)$ \\
\hline$>35$ & $60(7.95 \%)$ & $136(11.74 \%)$ \\
\hline Total & $754(100 \%)$ & $1158(100 \%)$ \\
\hline Mean Age & $30.51 \pm 4.32$ & $30.94 \pm 4.18$ \\
\hline
\end{tabular}

Mean BMI of the patients in both the groups was almost similar 23.69 $\pm 4.28,24.19 \pm 4.65$ in each group (Table 3).

Table 3: Distribution of patients according to BMI.

\begin{tabular}{|l|l|l|}
\hline BMII $\left(\mathrm{Kg} / \mathrm{m}^{2}\right)$ & Group 1(n- 754) & Group 2 (n-1158) \\
\hline $12.5-24.9$ & $525(69.61 \%)$ & $736(63.56 \%)$ \\
\hline $25-29.9$ & $187(24.2 \%)$ & $342(29.53 \%)$ \\
\hline$>30$ & $42(5.57 \%)$ & $80(6.91 \%)$ \\
\hline Total & $754(100 \%)$ & $1158(100 \%)$ \\
\hline Mean BMI & $23.69 \pm 4.28$ & $24.19 \pm 4.65$ \\
\hline
\end{tabular}

In group 1 i.e. Veress needle entry group the time interval between time of umbilical incision to the time of telescope removal was $4.5 \pm 1.2 \mathrm{~min}$ where as in group 2 (direct trocar entry group) was $2.2 \pm 0.8$ min giving a $\mathrm{p}$ value of $<0.001$. The amount of gas (in litres) required in the whole procedure was $4.9 \pm 1.3$ lts in group 1 in 
contrast to $2.4 \pm 0.5$ lts in group 2 with a p-value of $<0.001$ (Table-4).

Table 4: Duration of procedure and gas use.

\begin{tabular}{|l|l|l|l|}
\multicolumn{1}{|c|}{$\begin{array}{l}\text { Group 1 } \\
\text { Mean } \pm \text { SD }\end{array}$} & $\begin{array}{l}\text { Group 2 } \\
\text { Mean } \pm \text { SD }\end{array}$ & P-value \\
\begin{tabular}{|l|l|l|} 
Whole duration of \\
procedure (min)
\end{tabular} & $4.5 \pm 1.2$ & $2.2 \pm 0.8$ & $<0.0001$ \\
\hline Gas Use (litres) & $4.9 \pm 1.3$ & $2.4 \pm 0.5$ & $<0.0001$ \\
\hline
\end{tabular}

Number of patients who underwent previous surgeries including caesarean section and laparotomy for ectopic pregnancy in both the groups were almost comparable (Table 5).

Table 5: Previous surgeries in both groups.

\begin{tabular}{|l|l|l|}
\hline Previous surgery & Group 1 & Group 2 \\
\hline LSCS & $130(85.53 \%)$ & $231(86.5 \%)$ \\
\hline $\begin{array}{l}\text { Previous laparotomy } \\
\text { for ectopic pregnancy }\end{array}$ & $22(14.47 \%)$ & $36(13.5 \%)$ \\
\hline Total & 152 & 267 \\
\hline
\end{tabular}

There was no major complication seen in both the groups. Multiple attempts at abdominal entry and preperitoneal insufflations as minor complications were encountered in group 1 giving a p-value of $<0.001$. Other minor complications like periumbilical bruising, port site bleeding were almost similar in both the groups. Late complications like wound infection was seen in $1.1 \%$ of pts in group 1 and $1.2 \%$ of pts in group 2 respectively (Table 6).

Table 6: Minor complications encountered.

\begin{tabular}{|l|l|l|l|}
\hline $\begin{array}{l}\text { Minor } \\
\text { Complications }\end{array}$ & $\begin{array}{l}\text { Group 1 } \\
(\mathbf{n}-754)\end{array}$ & $\begin{array}{l}\text { Group 2 } \\
(\mathbf{n}-1158)\end{array}$ & P-value \\
\hline $\begin{array}{l}\text { Periumbilical } \\
\text { bruising }\end{array}$ & $6(0.8 \%)$ & $13(1.1 \%)$ & 0.481 \\
\hline Port site bleeding & $3(0.4 \%)$ & $8(0.6 \%)$ & 0.408 \\
\hline $\begin{array}{l}\text { Multiple attempts } \\
\begin{array}{l}\text { Preperitoneal } \\
\text { insufflation }\end{array}\end{array}$ & $22(2.9 \%)$ & $0(0 \%)$ & $<0.001$ \\
\hline Wound infection & $8(1.1 \%)$ & $14(1.2 \%)$ & 0.767 \\
\hline
\end{tabular}

Hence from the results we can conclude that Direct trocar entry is a safe technique to practice with no major complications.

\section{DISCUSSION}

Direct trocar insertion was first reported in the literature by Ding felder 10 in $1978 .{ }^{10}$ Bryon et al compared Veress needle and direct trocar entry in 252 women. They found a statistically significant in minor complications and longer insertion time in the Veress needle group. ${ }^{11}$ In the present study the mean duration of the procedure was comparatively shorter in group 2 than group $1 ;(2.2 \pm 0.8$, $4.5 \pm 1.2 \mathrm{~min})$. This is similar to that reported by Zakherah
MS. ${ }^{12}$ Inan et al and Prieto-Diaz Chavez et al. ${ }^{13,14}$ In the present study, there are no major complications encountered which is in close agreement with Zakherah MS and Theodoropoulou et al. ${ }^{12,15}$

Multiple attempts at insufflations and preperitoneal insufflations were more common in the group 1 than group 2 which is very much in accordance with Zakherah MS. ${ }^{12}$ According to Zakherah MS direct trocar group had only $2 \%$ of patients who underwent multiple attempts in contrast to Veress needle group where it was $14 \%$ giving a $\mathrm{P}$-value of $<0.0001$. Borgatta et al too reported fewer instrument insertions with direct trocar (7.8\%) as compared to Veress group (21.8\%). Incidence of minor complications such as periumbilical bruising, bleeding at port site, wound infection was almost similar in both the groups with a nonsignificant $\mathrm{p}$-value. ${ }^{16}$

Zakherah MS reported higher incidence of minor complications in Veress group as compared to Direct trocar entry group giving an incidence of $14 \%$ and $0.4 \%$ respectively which is comparable to Gunenc et al who reported complication rates of $15.7 \%$ and $3.3 \%$ with Veress and Direct trocar groups. ${ }^{12,17}$ On the other hand, Jacobson M.T et al reported increased incidence of late minor complications such as abdominal wall ecchymosis, wound infection/discharge, granulation tissue formation, delayed healing, minor oozing or bleeding in the direct trocar entry group $(2.04 \%)$ in contrast to $(0.75 \%)$ in Veress needle group. ${ }^{1}$

\section{CONCLUSION}

In conclusion, direct Trocar entry is a safe alternative to the Veress needle entry technique for the creation of pneumoperitoneum. One of the main advantages of this technique is the reduced number of the blind insertions required to gain abdominal access. Other benefits are rapid creation of pneumoperitoneum, less gas use and decreased operating time. In laparoscopic surgeries, it is a more reliable and less time-consuming method.

In the end, every surgeon should assess his own experience and in the light of this experience decide which is the best method for him to establish pneumoperitoneum taking into account the particular clinical situation and his own proficiency in each of the specific techniques.

Funding: No funding sources

Conflict of interest: None declared

Ethical approval: The study was approved by the Institutional Ethics Committee

\section{REFERENCES}

1. Jacobson MT et al. The Direct Trocar Technique : An Alternative Approach to Abdominal Entry for Laparoscopy. J Soc Laparoendos Surg. 2002;6(2):169-74. 
2. Manufacturer and User Facility Device Experience Database (MAUDE) (database online). Rockville, MD: US Food and Drug Administration. Available at http:// www.fda.gov.

3. Bhoyrul S, Vierra MA, Nezhat CR, Nezhat $\mathrm{CH}$, Krummel TM, Way LW. Trocar injuries in laparoscopic surgery. J Am Coll Surg. 2001;192(6): 677-83.

4. Patel PG, Chikhalia DP, Patel R, Jadav S, Dave AM. Direct Trocar Entry in Laparoscopic Surgeries: A Retrospective Study. Gastroenterol Hepatol J. 2017;1(109):29-33.

5. Jansen FW, Kapiteyn K, Trimbos-Kemper T, Hermans J, Trimbos J. Complications of laparoscopy: a prospective multicenter observational study. Br J Obstet Gynaecol. 1997;104(5):595-600.

6. Bateman BG, Kolp LA, Hoeger K. Complications of laparoscopy- operative and diagnostic. Fertil Steril. 1996;66(1):30-5.

7. Lehmann-Willenbrock E, Riedel HH, Mecke H, Semm K. Pelviscopy/laparoscopy and its complications in Germany 1949-1988. J Reprod Med. 1990;37(8):587-9.

8. Peterson HB, Hulka JF, Philips JM. American Association of Gynecologists and Laparoscopists 1988-member survey on operative laparoscopy . J Reprod Med.1990;35(6):587-9.

9. Harkki-Sirén P, Kurki T. A nationwide analysis of laproscopic complications. Obstet Gynecol. 1997;89(1):108-12.

10. Dingfelder JR. Direct laparoscopic trocar insertion without prior pneumoperitoneum . J Reprod Med. 1978;21(1):45-7.

11. Byron JW, Markensen G, Miyazawa K. A randomised comparison of Veress needle and trocar insertion for laparoscopy. Surg Gynecol Obstet. 1993;177(3):259-62.

12. Zakherah M.S. Direct Trocar versus Veress Needle Entry for Laparoscopy: A Randomised Clinical Trial.Gynecol Obstet Invest 2010;69(4):260-3.

13. Inan A, Sen M, Dener C, Bozer M. Comparison of direct trocar and Veress needle insertion in the performance of pneumoperitoneum in laparoscopic cholecystectomy . Acta Chir Belg. 2005;105(5):5158.

14. Prieto-Díaz-Chávez E, Medina-Chávez JL, González-Ojeda A, Anaya-Prado R, TrujilloHernández B, Vásquez C. Direct trocar insertion without pneumoperitoneum and the Veress needle in laparoscopic cholecystectomy: a comparative study. Acta Chir Belg 2006;106(5):541-4.

15. Theodoropoulou K, Lethaby DR, Bradpiece HA, Lo TL, Parihar A. Direct trocar insertion technique: an alternative for creation of pneumoperitoneum. JSLS 2008;12(2):156-8.

16. Borgatta L, Gruss L, Barad D, Kaali SG: Direct trocar insertion vs Veress needle for laparoscopic sterilization. J Reprod Med 1990;35(9):891-4

17. Günenç MZ, Yesildaglar N, Bingöl B, Önalan G, Tabak S, Gökmen B. et al: The safety and efficacy of direct trocar insertion with elevation of the rectus sheath instead of the skin for pneumoperitoneum.Surg Laparosc Endosc Percutan Tech. 2005;15(2):80-1.

Cite this article as: Sinha S, Malik S. Veress needle versus direct trocar entry for laparoscopy: a retrospective study. Int J Reprod Contracept Obstet Gynecol 2019;8:127-30. 